J. Egypt. Soc. Parasitol. (JESP), 51(1), 2021: 79 - 88

(Online: 2090-2549)

\title{
AMELORATIVE AND HEPATOPROTECTIVE EFFECTS OF FISETIN ON ACUTE MURINE TOXOPLASMOSIS
}

By

DALIA A. ELMEHY ${ }^{1 *}$, AMINA M. SALAMA ${ }^{1}$, NEMA A. SOLIMAN ${ }^{2}$, REEM A.

ELKHOLY ${ }^{3}$, DINA M. TAHOON ${ }^{3}$, RASHA F. MADY ${ }^{4}$, and GHADA A. GAMEA ${ }^{1}$

Departments of Medical Parasitology ${ }^{1}$, Medical Biochemistry ${ }^{2}$, and Medical

Pharmacology ${ }^{3}$, Faculty of Medicine, Tanta University, and Department of Medical

Parasitology ${ }^{4}$, Faculty of Medicine, Alexandria University, Egypt.

$\left({ }^{*}\right.$ Correspondence: dalia.elmehy@med.tanta.edu.eg

- ORCID: https://orcid.org/0000-0001-5590-3424)

\section{Abstract}

Toxoplasma gondii (T. gondii) protozoan invades any nucleated cell with a special predilection to reticuloendothelial cells. Liver is severely affected during acute toxoplasmosis. Promisingly, fisetin (FIS) flavonoid was proved to have antioxidant, anti-inflammatory, anti-cancerous, and anti-protozoal effects. This study was designed to evaluate the anti-Toxoplasma effect and the hepatoprotective potential of FIS in vivo. Mice were infected with the virulent RH strain of $T$. gondii in a dose of $1 \times 10^{3}$ tachyzoites/mouse. Mice were divided into seven equal groups: G1: healthy control, G2: infected control, G3: Pyrimethamine ${ }^{\circledR}$ (PYR)/sulfadiazine (SDZ)), G4: oral-FIS, G5: oral-FIS+ PYR treated, G6: intraperitoneal (I.P) FIS, and G7: I.P FIS+PYR treated. Survival rate was estimated, and tachyzoites were counted in liver impression smears. Liver enzymes and $C$ reactive protein (CRP) were measured in mice sera. Liver tissues were examined for inflammatory mediators; cyclooxygenase 2 (COX2 ), interleukin (IL) -10, IL-12, IL-1 $\beta$, oxidative mediators; inducible nitric oxide synthase (iNOS), myeloperoxidase (MPO), and malondialdehyde (MDA) FIS showed a moderate effect on parasite survival and tachyzoites count, with an excellent effect in reducing serum liver enzymes activity and proinflammatory mediators. Combined (FIS+PYR) showed the best anti-parasitic and hepatoprotective actions. Its administration I.P. gave significant cure compared to oral route. FIS when given I.P than oral FIS had a good anti-inflammatory and antioxidant effect, decreased inflammatory cytokines and improved hepatic pathology of acute toxoplasmosis. Combined FIS/PYR was the best drug regimen.

Keywords: Toxoplasma gondii, Fisetin, Arginase inhibitor, Oxidative stress, iNOS; Interleukins, Liver enzymes.

\section{Introduction}

Toxoplasmosis (T. gondii), a worldwide distributed zoonosis that can be transmitted congenitally affecting fetuses. Different genotypes and infective dose were related factors causing different clinical manifestations (Pardini et al, 2019). Apart from congenital trans-mission infection could be acquired by ingestion or inhalation of oocysts from cat feces (Al-Kappany et al, 2010) or from consumption of undercooked infected meat (Belluco et al, 2016) or blood transfusion (Step-hen et al, 2017) or organ transplantation (Saadatnia and Golkar, 2012) or nosocomial by needle-stick injury (AbdelMotagaly et al, 2017). Toxoplasmosis is a disease with clinical manifestations and symptoms (Andrade et al, 2006). In immutreatment was pyrimethamine ${ }^{\circledR}$ (PYR) and sulfadiazine $^{\circledR}$ (SDZ) combination (Silva et nocompetent individuals, the acute phase of infection was presented as transient unnoticed low or mild symptoms, but in immunocompromised patients, $T$. gondii is a lifethreatening opportunistic infection, resulted from reactivated la-tent infection or primary infection. But congenital toxoplasmosis resulted from trans-placental passage of tachyzoites into fetus during a pregnant primary infection, led to miscarriage, habitual abortion, stillbirth, neonatal death, or ocular and neurologic disease, and neurocognitive deficits in the newborns (Manuel et al, 2020).

Consequently, prophylaxis and treatment of toxoplasmosis were indicated particularly among childbearing aged females (Saleh et al, 2014). The widely used toxoplasmosis al, 2019), particularly in USA (Butler et al, 2013), Egypt (Al-Agroudi et al, 2017), and 
France (Chemla and Villena, 2017). But, the combination of pyrimethamine/sulfadiazine was more or less not safe in the first trimester of pregnancy due to their serious teratogenic effects (Peters et al, 2007). Spiramy$\operatorname{cin}^{\circledR}$ was safely alternative given during pre gnancy, but with less efficacy and possible harmful effects on the fetus (Wei et al, 2015). So, many authors returned to the medicinal plants \& herbs with phenolic constituents (Abdel-Hady et al, 2014).

Flavonoids natural polyphenolic compounds with many biological roles were considered as potential therapeutic agents ( $\mathrm{Li}$ et al, 2012). Fisetin or FIS (3, 7, 3', 4'-tetrahydroxyflavone) is a natural flavonoid found in green vegetables and fruits as grapes, apples, strawberries, persimmons, onions, and cucumbers (Grynkiewicz and Demchuk, 2019). It is poorly absorbed from the gastrointestinal tract as it has low aqueous solubility and bioavailability (Kashyap et al, 2018). FIS obey the first-order reaction in degradation mediated by oxidation, hydroxylation, and ring-cleavage (Wang and Zhao, 2016). Flavonoids supplements dietary during pregnancy was safe without side effects (Barenys $e t$ al, 2017). Also, FIS flavonoid showed an anti-protozoal action against Plasmodium $\mathrm{fa}$ lciparum, Trypanosoma brucei, Cryptosporidium parvum, Entamoeba histolytica and Giardia lamblia (Martínez-Castillo et al, 2018). It has antioxidant, anti-angiogenic, anti-inflammatory, antitumor, senotherapeutic, and neuroprotective effectivities (Grynkiewicz and Demchuk, 2019). The anti-inflammatory mechanism of FIS reduced the expression and activity of cyclo-oxygenase 2 (COX-2) enzymes and several pro-inflammatory cytokines formation (Kim et al, 2012).

This study aimed to evaluate the antioxidant, anti-inflammatory, and anti-parasitic effect of FIS (oral and intraperitoneal, I.P.) on the $\mathrm{RH}$ virulent strain of $T$. gondii in experimental infected mice, Also, to evaluate the efficacy of the FIS to replace sulfadiazine ${ }^{\circledR}$ in combination with pyrimethamine ${ }^{\circledR}$, which is the golden drug for toxoplasmosis.

\section{Materials and Methods}

Parasite and experimental animals: The virulent $T$. gondii RH HXGPRT (-) strain was maintained in Parasitology Department, Faculty of Medicine, Alexandria University by serial I.P passages of tachyzoites in parasitefree laboratory-bred Swiss albino mice. The peritoneal exudate was harvested on the fifth day post-inoculation and then diluted in phosphate buffered saline $(\mathrm{pH}=7.4)$. A total of 112 clean laboratory-bred male Swiss Albino mice (6-8 weeks old, 20gm weight) were caged at room temperature with $12 / 12$ $\mathrm{h}$ light/dark cycles and allowed access to commercial rodent chow and tap water via the experimental period. Mice were I.P infected by $1 \times 10^{3}$ tachyzoites/ mouse (Leesombun et al, 2016).

Drug regimen: FIS was purchased (SigmaAldrich St. Louis, USA) and diluted in carboxymethyl cellulose (CMC); $0.5 \mathrm{gm} / 100 \mathrm{ml}$. given both orally or I.P in a dose of $100 \mathrm{mg} /$ $\mathrm{kg}$ /day for 5 days (Xu and $\mathrm{Li}, 2018$ ). PYR were purchased (Sigma- Aldrich) and diluted in $\mathrm{CMC}$ as $0.5 \mathrm{gm} / 100 \mathrm{ml}$, and given orally, in combination as 12.5 or $250 \mathrm{mg} / \mathrm{kg} /$ day, respectively for 5 days. Treatment started on the infection day up to 5 days (El Kowrany et al, 2019).

Experiment: 112 mice were divided into seven groups of 16 mice each: G1: Normal non infected (control negative), G2: Infected non treated control (control positive), G3: PYR/SDZ treated (drug control), G4: FIS oral-treated (oral-FIS), G5: Combined oraltreated with both FIS+ PYR, G6: FIS I.Ptreated and G7: Combined I.P. FIS with oral PYR (I.P-FIS+ oral PYR). Ten mice were left for survival rate estimation and six were sacrificed on $5^{\text {th }}$ day post infection (dpi). Parasitological studies: Survival rate (SR) was calculated due to following equation:

$$
\mathrm{SR}=\text { Number of live mice at scarification time }
$$

Number of mice experimented with.

The SR was calculated in the experimental subgroups in comparison to corresponding controls at the time of sacrifice (El-Zawawy, 2008). Tachyzoites count was determined after mice scarification a small piece of liver 
was cut, dried on filter paper, and used to do impression smears. Tachyzoites were counted in Giemsa stained impression smears by oil immersion lens; ten fields/mouse (Al Dakhil and Morsy, 1996).

Biochemical studies: Liver tissues were rinsed with cold saline, dried, and weighed then homogenized in 4 volumes of $50 \mathrm{ml}$ PBS (pH 7.2) followed by centrifugation at $12,000 \mathrm{xg}$ for $15 \mathrm{~min}$ at $4^{\circ} \mathrm{C}$. The supernatants were frozen at $-80^{\circ} \mathrm{C}$ until the analysis time. Liver protein content was determined (Lowery et al, 1951). Colorimetric assay of inducible nitric oxide synthase (iNOS) activity was measured (Ryoyama et al, 1993). Its activity was represented as U/mg protein. Liver tissue myeloperoxidase (MPO) enzyme activity was assayed (Xia and Zweier, 1997) using O-dianisidine and $\mathrm{H}_{2} \mathrm{O}_{2}$, change in absorbance was measured spectrophotometrically at the $460 \mathrm{~nm}$. Malondialdehyde (MDA) level was assayed using purchased kits (Biodiagnostic, Giza, Egypt). Interleukin-1beta (IL-1 $\beta$ ) \& COX-2 levels in liver tissue were assayed using purchased ELISA kits (Abcam, Cambridge, UK, Catalog Nos: ab210574 \& ab100704, respectively). Liver tissue IL-10, IL-12 was assayed using purchased ELISA kits (Ra-ybiotech. Inc., Parkway, USA, Catalog Nos: ELM-IL10 \& ELM-IL12P40P70, respectively). On scarification day, blood samples were collected, sera separate by centrifugation and frozen at $-80^{\circ} \mathrm{C}$ for liver enzymes analysis.

The liver AST and ALT were determined using purchased diagnostics kits (Elitech, Paris, France). Serum $C$ reactive protein (CRP) level was assayed using purchased ELISA kits (R \& D Systems Shanghai, China, Catalog No: MCRP00). All ELISA techniques were done according to the manufacturer's protocol and read on a microplate reader (Stat Fax ${ }^{\circledR} 2100$, Fisher Bioblock Scientific, France) at $450 \mathrm{~nm}$ with a correction wave length set at $570 \mathrm{~nm}$.

Ethical consideration: This research was conducted in accordance with the guidelines of the Ethical Committee of Medical Resea- rch, Faculty of Medicine, Alexandria University, Egypt (approval code:0304515). All chemicals and solvents used were of high analytical value.

Statistical analysis: Data was fed to the computer and analyzed using SPSS software package version 20.0. ANOVA was used for comparing the studied groups followed by Post Hoc test (Tukey) for pairwise comparison. Kaplan-Meier survival curve was used for the significant relationship with overall survival. Significance was judged at 5\% level (Kotz et al, 2006).

\section{Results}

Survival rate: On the $9^{\text {th }}$ dpi, all infected control mice died, while $60 \%$ of PYR/SDZ mice survived. FIS enhanced the survival rate of mice when administered I.P as compared to the infected control group ones $(30 \%)$ when used alone and $(60 \%)$ when combined with PYR on the $9^{\text {th }}$ dpi. Oral FIS alone failed to prolong mice survival beyond $6^{\text {th }}$ dpi (Fig. 1).

Tachyzoites count: Mean count in liver impression smears of infected control group was $7.0 \pm 2.61$ (Fig. 2). But, PYR/SDZ significantly reduced tachyzoites count with a mean of $0.67 \pm 0.82(\mathrm{P}<0.001)$. Least tachyzoites count was in mice received combination of PYR \& I.P-FIS with a mean of $0.50 \pm 0.84(\mathrm{P}<0.001)$. I.P-FIS alone significantly reduced tachyzoites count with a mean of $3.17 \pm 1.94(\mathrm{P}<0.001)$. Oral- FIS gave no significance tachyzoites reduction as compared with infected control mice.

Oxidative stress biomarkers: The levels of iNOS, MPO, and MDA in liver tissues showed a reduction in all treated groups as compared to the infected control mice. Marked reduction was in mice treated with orally FIS+PYR and I.P-FIS+PYR with significant differences, particularly the FIS+PYR treated ones (Tab. 2).

Inflammatory cytokines: Significant elevation of IL-12 \& IL-1 $\beta$ in liver tissues was in the infected control group (compared to the normal control group. Levels of IL-12 \& IL$1 \beta$ in all treated groups showed a significant 
reduction as compared to the infected control mice. High significant reduction was in mice treated with oral-FIS+PYR \& I.P-FIS+ PYR. COX-2 levels significant increase in the infected untreated mice as compared to normal ones. FIS alone or combined with PYR showed significant reduction (Tab. 3).

Anti-inflammatory cytokine; IL-10, showed a significant decrease level in liver tissues of infected control mice as compared to normal control ones. Also, there was significant $(\mathrm{P}<0.001)$ increase of IL-10 levels in all treated mice as compared to infected control mice, especially in combined treatment
(oral-FIS+PYR \& I.P-FIS+PYR) as compared the infected untreated mice (Tab. 3).

Liver enzymes: ALT \& AST showed significant increase in infected non treated mice as compared to normal controls $(\mathrm{P}<0.001)$. FIS- treated groups (oral or I.P) showed a significant decrease as compared to PYR/ SDZ treated mice especially in mice received I.P FIS and PYR (Tab. 4). Serum CRP showed a significant increase in infected untreated mice as compared to all treated ones that showed a significant decrease especially in mice received I.P FIS and PYR (Tab. 4).

Table 1: Comparison between groups as to tachyzoites count (n=6)
\begin{tabular}{|l|l|c|c|}
\hline Group & Tachyzoite count & F. test & Post Hock test \\
\hline G2 & $7 \pm 2.6$ & \multirow{2}{*}{$17.391^{*}$} & $0.001^{*}$ \\
G3 & $0.67 \pm 0.82^{\mathrm{a}}$ & & \\
\hline G4 & $6.7 \mathrm{~b} \pm 2.9^{\mathrm{b}}$ & & \\
\hline G5 & $0.7 \pm 0.8^{\text {ac }}$ & \\
G6 & $3.2 \pm 1.9^{\text {abcd }}$ & & \\
\hline G7 & $0.5 \pm 0.8^{\text {ace }}$ & & \\
\hline
\end{tabular}

P-value: a=significant with $\mathrm{G} 2, \mathrm{~b}=$ signifi- $\mathrm{d}=$ significant with $\mathrm{G} 5$, e $=$ significant with cant with G3, $\mathrm{c}=$ significant with G4, G6. $*$ Significant at $\mathrm{p} \leq 0.05$

Table 2: Comparison between different groups according to oxidative stress parameters $(n=6)$

\begin{tabular}{|l|c|c|c|}
\hline Group & iNOS activity (U/mg protein) & MDA level nmol/mg protein & MPO activity, U /mg protein \\
\hline G1 & $27.4 \pm 6$ & $1.2 \pm 0.2$ & $1.7 \pm 0.3^{\mathrm{a}}$ \\
\hline G2 & $77.3 \pm 5.3^{\mathrm{a}}$ & $4.8 \pm 0.9^{\mathrm{a}}$ & $7 \pm 0.9^{\mathrm{a}}$ \\
\hline G3 & $54.2 \pm 2.7^{\mathrm{ab}}$ & $3.7 \pm 0.4^{\mathrm{ab}}$ & $6.2 \pm 0.8^{\mathrm{ab}}$ \\
\hline G4 & $74.1 \pm 4.5^{\mathrm{ac}}$ & $4.9 \pm 0.2^{\mathrm{ac}}$ & $6.2 \pm 0.4^{\mathrm{ab}}$ \\
\hline G5 & $51.8 \pm 2.5^{\text {abd }}$ & $2.6 \pm 0.5^{\text {abcd }}$ & $4.9 \pm 0.2^{\text {abcd }}$ \\
\hline G6 & $57.4 \pm 2^{\text {abd }}$ & $3 \pm 0.4^{\text {abcd }}$ & $4.3 \pm 0.3^{\text {abcde }}$ \\
\hline G7 & $56.4 \pm 7.8^{\text {abd }}$ & $1.9 \pm 0.2^{\text {abcdef }}$ & $2.9 \pm 0.3^{\text {abcdef }}$ \\
\hline F & $57.932^{*}$ & $45.796^{*}$ & $71.627^{*}$ \\
\hline p & $0.001^{*}$ & $0.001^{*}$ & $0.001^{*}$ \\
\hline
\end{tabular}

P-value: $a=$ significant with $\mathrm{G} 1, \mathrm{~b}=$ signif- nificant with $\mathrm{G} 4, \mathrm{e}=$ significant with $\mathrm{G} 5, \mathrm{f}=$ icant with $\mathrm{G} 2, \mathrm{c}=$ significant with $\mathrm{G} 3, \mathrm{~d}=$ sig- $\quad$ significant with G6.*Significant at $\mathrm{p} \leq 0.05$

Table 3: Comparison between different groups as to pro-inflammatory and anti-inflammatory mediators in liver tissues ( $\mathrm{n}=6$ )

\begin{tabular}{|c|c|c|c|c|}
\hline Group & $\begin{array}{c}\text { IL-12 level, pg/mg } \\
\text { protein }\end{array}$ & $\begin{array}{c}\text { IL-1B level, } \\
\text { pg/mg protein }\end{array}$ & $\begin{array}{c}\text { COX-2 level, } \\
\text { ng/mg protein }\end{array}$ & $\begin{array}{c}\text { IL-10 level, } \\
\mathrm{pg} / \mathrm{mg} \text { protein }\end{array}$ \\
\hline G1 & $62.6 \pm 5.6$ & $56.6 \pm 5.6$ & $3.8 \pm 0.7$ & $111.6 \pm 8.6$ \\
\hline G2 & $165.7 \pm 12.1^{\mathrm{a}}$ & $162.5 \pm 30.9^{\mathrm{a}}$ & $8.8 \pm 0.6^{\mathrm{a}}$ & $60.3 \pm 7.7^{\mathrm{a}}$ \\
\hline G3 & $92.3 \pm 2.2^{\mathrm{ab}}$ & $88.9 \pm 1.4^{\mathrm{ab}}$ & $6.9 \pm 0.6^{\mathrm{ab}}$ & $70 \pm 5.9^{\mathrm{ab}}$ \\
\hline G4 & $129.7 \pm 26.9^{\mathrm{abc}}$ & $152.7 \pm 25.4^{\mathrm{ac}}$ & $7.3 \pm 0.8^{\mathrm{ab}}$ & $60.5 \pm 1.3^{\mathrm{ac}}$ \\
\hline G5 & $87 \pm 3.4^{\text {abd }}$ & $82.3 \pm 2.4^{\mathrm{bd}}$ & $5.9 \pm 0.2^{\text {abcd }}$ & $80 \pm 3.8^{\text {abcd }}$ \\
\hline G6 & $91.1 \pm 4.1^{\text {abd }}$ & $111.8 \pm 43.9^{\text {abde }}$ & $6.6 \pm 0.6^{\mathrm{ab}}$ & $68.9 \pm 1.9^{\text {abde }}$ \\
\hline G7 & $79.4 \pm 1.5^{\text {abd }}$ & $68 \pm 5.4^{\text {bdf }}$ & $5.4 \pm 0.4^{\text {abcdf }}$ & $93.5 \pm 3^{\text {abcdef }}$ \\
\hline F & $45.656^{*}$ & 16.414 & $35.546^{*}$ & $63.506^{*}$ \\
\hline p & $0.001^{*}$ & $0.001^{*}$ & $0.001^{*}$ & $0.001^{*}$ \\
\hline
\end{tabular}

$P$ value: $a=$ significant with $G 1, b=$ significant with G2, c=significant with G3, d= sig- nificant with $\mathrm{G} 4, \mathrm{e}=$ significant with $\mathrm{G} 5, \mathrm{f}=$ significant with G6. * Significant at $p \leq 0.05$. 
Table 4: Comparison between groups as to serum liver enzymes and serum CRP $(n=6)$

\begin{tabular}{|l|l|l|l|}
\hline Group & ALT activity (IU/L) & AST $(\mathrm{IU} / \mathrm{L})$ & $\mathrm{CRP} \mathrm{ng} / \mathrm{mL}$ \\
\hline G1 & $26.8 \pm 2.1$ & $27.5 \pm 2$ & $1.2 \pm 0.3$ \\
\hline G2 & $89.9 \pm 4.7^{\mathrm{a}}$ & $101.3 \pm 3.1^{\mathrm{a}}$ & $4 \pm 0.6^{\mathrm{a}}$ \\
\hline G3 & $74 \pm 8.7^{\mathrm{ab}}$ & $89.5 \pm 1.5^{\text {ab }}$ & $3.1 \pm 0.3^{\mathrm{ab}}$ \\
\hline G4 & $65.3 \pm 4.5^{\text {abc }}$ & $83.8 \pm 2^{\text {abc }}$ & $3 \pm 0.4^{\text {ab }}$ \\
\hline G5 & $61 \pm 2.6^{\text {abc }}$ & $80.8 \pm 1.4^{\text {abc }}$ & $2.2 \pm 0.3^{\text {abcd }}$ \\
\hline G6 & $66.5 \pm 1.7^{\text {abc }}$ & $77.2 \pm 7.3^{\text {abcd }}$ & $2.7 \pm 0.6^{\text {ab }}$ \\
\hline G7 & $41.4 \pm 1.8^{\text {abcdef }}$ & $51.6 \pm 4.2^{\text {abcdef }}$ & $1.8 \pm 0.4^{\text {abcdf }}$ \\
\hline F & $112.50^{*}$ & $239.252^{*}$ & $23.191^{*}$ \\
\hline p & $0.001^{*}$ & $0.001^{*}$ & $0.001^{*}$ \\
\hline
\end{tabular}

$P$ value: $a=$ significant with $G 1, b=$ significant with G2, c=significant with G3, d= sig-

\section{Discussion}

Flavonoids are unique phytocompounds that can be considered promising natural candidates for safe drug manufacture (Merken and Beecher, 2000). FIS flavonoid compound gave promising results against Plasmodium falciparum and Leishmania major (Manjolin et al, 2013). Combined therapeutic compounds decreased toxicity and resistance of traditionally known drugs (Mesquita et al, 2014).

In the present study, FIS extended the life of the T. gondii infected mice in groups G4 and G6. Moreover, it significantly reduced the mean tachyzoites count in liver impression smears. Manjolin et al. (2013) referred the anti-parasitic effect of flavonoid compounds to their inhibition of arginase enzyme (ARG-L). The ARG-L hydrolyses 1arginine into 1-ornithine and urea as the first step of polyamines biosynthesis (Colotti and Ilari, 2011). Polyamines are valuable targets for antiparasitic chemotherapy because they play an important role in the proliferation, differentiation and synthesis of macromolecules, and in the antioxidant pathways of intracellular parasites as Leishmania species (Birkholtz et al, 2011). The FIS is a potent ARG-L inhibitor with extremely higher potency than other flavonoid compounds such as quercetin and luteolin, respectively. Comparing the structures of these flavonoids revealed that the hydroxyl group at position 3 contributed significantly to its effect as an arginase inhibitor. L-arginine is one of the most versatile amino acids that is found in all tissues and microorganisms and used as a nificant with $\mathrm{G} 4$, e:= significant with $\mathrm{G} 5, \mathrm{f}=$ significant with G6. * Significant at $\mathrm{p} \leq 0.05$. precursor for protein synthesis (Manjolin et al, 2013).

Another proved mechanistic potential of FIS is that it promotes apoptosis mediated by inhibition of topoisomerase II, a crucial enzyme for DNA replication and translation resulting in kinetoplast DNA cleavage in $T$. gondii (García-Estrada et al, 2010). Other studies attributed its antimicrobial effect to inhibition of tyrosine, calcium-dependent protein kinases, mitochondrial functions, and fatty acid type II synthesis (Chiang et al, 2015). Hence, the current treatment with FIS has the potential to disrupt these essential enzymes in $T$. gondii, which are key to parasite survival, invasion, gliding motility, proliferation, egress, and post-egress modification. When these actions are added to the inhibition of folate biosynthesis pathways targeted by PYR, the significant effectiveness of combined treatment can be easily justified (Abugri and Witola, 2020).

Many studies have indicated that the liver is severely affected during acute toxoplasmosis as manifested by hepatic pathologies, such as hepatomegaly, hepatitis and granuloma (Weitberg et al, 1979). Furthermore, necrosis, cholestatic jaundice, cirrhosis with subsequent hepatocyte destruction, and shooting of liver enzymes also occur (Mordue et al, 2001).

In the present study, after FIS treatment, the liver cell damage degree was markedly diminished as manifested by the strong reduction of ALT \& AST to normal level. This agreed with $\mathrm{Pu}$ et al. (2017) in China who reported that the FIS alleviated the hepato- 
cyte injury and reduced transaminase activities. In the present study, the hepato-protective effect mediated by FIS (alone or in combination) was thought to be not only due to parasite dampening, but also to the well expected antioxidant and anti-inflammatory effects of FIS, which agreed with Pal et al. (2016).

In the current study, I.P administration of FIS reported significant amelioration compared to oral form. This could be explained by its low oral bioavailability (Mehta et al, 2018). Regarding combined FIS treatment with PYR in the present experiment, mice which received both drugs (G5 and G7) showed better amelioration when compared with other treated groups. It is noteworthy to mention that this combination has the benefit of parasite killing, by the antifolate effect of PYR as well as liver protection by FIS.

Oxidative stress biomarkers in $T$. gondii experimentally infected mice in the current work expressed marked reduction of their levels in liver tissues in all FIS treated mice denoting its powerful antioxidant effect. During infection, $T$. gondii stimulates Type1 immune response which stimulates macrophages and iNOS expression with subsequent increase in the NO levels which directly destroys the parasite but with a very harmful effect on the hepatocytes as well (Naeem et al, 2018). Meanwhile, Woods et al. (2013) reported that mice lacking iNOS can survive and control infection by interferon gamma (IFN- $\gamma$ ) derived mechanisms. However, mice died during chronic infection due to increased proliferation of tachyzoites in the brain, suggesting that iNOS was protective in the brain.

Measurement of MDA was the indicator of lipid peroxidation that occurs when parasites cause injury to the tissues of the host. The study results regarding the levels of MDA and MPO in liver tissues showed a reduction of their levels in all FIS treated groups when compared with the infected control group. This can be explained by the fact that the antioxidant effects of FIS, as a flavone, may be structure-related where FIS showed the marked free radical scavenging activities against the various reactive oxygen species. This agreed with Manjolin et al. (2013) who recorded antioxidant effects of flavonoids in amebiasis, as well as Sahu et al. (2014) who proved the antioxidant effect of FIS in nephrotoxicity. Besides, Dincel et al. (2016) reported that the suppressed oxidative stress by the FIS proved to prevent the activation of hepatic apoptotic signaling consequently protecting the liver cells.

Measurement of the inflammatory mediators showed their significant reduction after treatment with FIS (G4 and G6). According to Li et al. (2018), Toxoplasma exosomes can be transmitted from one cell to another without the need for tachyzoites to invade the cell. Exosomes can stimulate the secretion of various cytokines and modulate host immune response that favors the parasite survival. IL-12 is one of these cytokines that is produced after infection in large amounts. This finding directs the thoughts regarding these cytokines in that they are not usually beneficial to the host, and their overproduction is nothing but a plan of action from the parasite itself allowing it to manage its weapons. Therefore, the significant decrease of IL-12 and IL- $1 \beta$ levels after treatment with FIS in this study would pave the way for novel modalities regarding the immunomechanistic potentials in the toxoplasmosis treatment. This outcome suggestion agreed with both Maher et al. (2011) and FarsadNaeimi et al. (2018) reported that the FIS proved to be the potent anti-inflammatory agent through down-regulation of different genes involved in inflammatory response including nuclear factor $\kappa \mathrm{B}(\mathrm{NF}-\mathrm{\kappa B})$ and its downstream signaling cascade. With the FIS treatment, levels of IL-1 $\beta$ and IL-12 decreased significantly despite their well-known role in innate and adaptive immune responses against toxoplasmosis. This finding drew the attention and supported the assumption that FIS can help as an adjunctive treatment with PYR for its hepatoprotective as well as 
its anti-inflammatory role in addition to its direct antiparasitic effect.

The results of Pereira et al. (2019) ran hand in hand with the current findings, as they showed that COX-2 is a modulator of the immune response in toxoplasmosis infection. The COX-2 inhibitors dampen Toxoplasma proliferation since inhibition of such enzyme upregulated important pro-inflammatory mediators against toxoplasmosis. Although this finding supports the beneficial role of FIS, the upregulation of proinflammatory mediators may contradict its role as an anti-inflammatory flavonoid compound.

In the current study, treated mice showed a significant reduction in proinflammatory mediators such as; CRP, COX-2, IL-12, and IL-1 $\beta$ with subsequent improvement of their deleterious effects on hepatocytes. Although these cytokines activate important immune cells and stimulate the production of IFN- $\gamma$ to get rid of the parasite, their uncontrolled release has an unfavorable effect on hepatocytes. This could be the key in the hepatoprotective effect of FIS. The IL-10 increased significantly with FIS treatment and this is expected because IL-10 is an anti-inflammatory cytokine that downregulates $\mathrm{TH}-1$ cell function. It plays an immunoprotective role and improved pregnancy outcome of $T$. gondii-infected mice (Zhang et al, 2012). Also, Chamcheu et al. (2019) reported that FIS upregulated IL-10 with its pleiotropic effects including anti-inflammatory activities that were found in various models.

\section{Conclusion}

The outcome data reported the hepatoprotective impact of FIS on acute virulent toxoplasmosis in mice as one of the promising flavonoids. FIS exerted excellent role in the protection of hepatocytes by its anti-inflammatory, antioxidant and anti-parasitic potentials. This explains the best outcomes achieved with combination treatment in which the FIS shared PYR in parasite killing. The current results pave the way for more research to encourage FIS use in combination with
PYR in toxoplasmosis treatment.

Conflict of interest: The authors declared that they neither have conflict of interest nor received fund.

\section{References}

Abdel-Hady, NM, El-Hela, AA, Morsy, TA, 2014: Phenolic content of some selected Lamiaceous Egyptian medicinal plants: Antioxidant potential and ecological friend mosquito-larvicidal. J. Egypt. Soc. Parasitol. 44, 1:21-4

Abdel-Motagaly, AME, Ibrahim, AMA, Morsy, TA, 2017: An intervention program on blood protozoa acquired by needle stick injury and infection control. J. Egypt. Soc. Parasitol. 47, 2: 309-22

Al-Agroudi, MA, Ahmad, GMS, Kondo, MK, Morsy, TA, 2017: An overview of congenital toxoplasmosis: Clinical features, diagnosis, treatment and prevention. J. Egypt. Soc. Parasitol. 47, 3:523-40.

Al-Kappany, YM, Rajendran, C, Ferreira, L R, Kwok, OC, Abu-Elwafa, SA, et al, 2010: High prevalence of toxoplasmosis in cats from Egypt: Isolation of viable Toxoplasma gondii, tissue distribution, and isolate designation. J. Parasitol. 96, 6:1115-8.

Andrade, GMQ, Tonelli, E, Oréfice, F, 2006: Toxoplasmose egestação. In: Couto JCF, Andrade GNQ, Tonelli E, editors. Infecções Perinatais. Rio de Janeiro: Guanabara Koogan.

Abugri, DA, Witola, WH, 2020: Interaction of apigenin-7-O-glucoside with pyrimethamine against Toxoplasma gondii growth. J. Parasit. Dis. 44:221-9.

Al Dakhil, MA, Morsy TA, 1996: Natural Toxoplasma infection sought in the Indian grey mongoose (H. Edwardsi, Greffroy, 1818) trapped in the eastern region, Saudi Arabia. J. Egypt. Soc. Parasitol. 26, 3:645-52.

Barenys, M, Masjosthusmann, S, Fritsche, E, 2017: Is intake of flavonoid-based food supplements during pregnancy safe for the developing child? A literature review. Curr. Drug Targ. 18: 196-231.

Butler, NJ, Furtado, JM, Winthrop, KL, Smith, JR, 2013: Ocular toxoplasmosis II: Clinical features, pathology and management. Clin. Exp. Ophthalmol. 41, 1:95-108

Belluco, S, Mancin, M, Conficoni, D, Simonato, G, Pietrobelli, M, et al, 2016: Investigating the determinants of Toxoplasma gondii prevalence in meat: A systematic review and meta-re- 
gression. PLoS One 11, 4:e0153856.

Birkholtz, M, Williams, M, Niemand, J, Louw, AI, Persson, L, et al, 2011: Polyamine ho moeostasis as a drug target in pathogenic protozoa: Peculiarities and possibilities. Biochem. J. 438:229-44.

Chamcheu, JC, Esnault, S, Adhami, VM, NoIl, AL, Banang-Mbeumi, S, et al, 2019: Fisetin, a 3, 7, 3', 4'-Tetrahydroxyflavone inhibits the $\mathrm{PI} 3 \mathrm{~K} / \mathrm{Akt} / \mathrm{mTOR}$ and MAPK pathways and ameliorates psoriasis pathology in 2D and 3D organotypic human inflammatory skin models. Cells 8:1089.

Chemla, C, Villena, I, 2017: Sulfadoxine/pyrimethamine combination in congenital toxoplasmosis. Pediatr. Infect. Dis. J. 36, 3:349-50.

Chiang, HM, Chan, SY, Chu, Y, Wen, KC, 2015: Fisetin ameliorated photodamage by suppressing the mitogen-activated protein kinase/ matrix metalloproteinase pathway and nuclear factor- $\kappa$ B path-ways. J. Agric. Food. Chem. 63: 4551-60.

Colotti, G, Ilari, A, 2011: Polyamine metabolism in Leishmania from arginine to trypanothione. Amino acids 40:269-85.

Dincel, GC, Atmaca, HT, 2016: Role of oxidative stress in the pathophysiology of Toxoplasma gond-ii infection. Int. J. Immunopathol. Pharmacol. 29:226-40.

El-Kowrany, SI, El Ghaffar, AEA, Shoheib, ZS, Mady, RF, Gamea, GAM, 2019: Evaluation of nitazoxanide as a novel drug for the treatment of acute and chronic toxoplasmosis. Acta Trop. 95:145-54.

El-Zawawy, LA, 2008: Effect of artesunate on Toxoplasma gondii: In vitro and in vivo studies. J. Egypt. Soc. Parasitol. 1, 2:185-201.

Farsad-Naeimi, A, Alizadeh, M, Esfahani, A, Aminabad, ED, 2018: Effect of fisetin supplementat-ion on inflammatory factors and matrix metalloproteinase enzymes in colorectal cancer patients. Food Funct. 9:2025-31.

García-Estrada, C, Prada, CF, FernándezRubio, C, Rojo-Vázquez, F, Balaña-Force, $R$, 2010: DNA topoisomerases in apicomplexan parasites: Promising targets for drug discovery. Proc. Biol. Sci. 277:1777-87.

Grynkiewicz, G, Demchuk, OM, 2019: New perspectives for fisetin. Front. Chem.7:697-9.

Li, CC, Lo, HY, Hsiang, CY, Ho, TY, 2012:

DNA microarray analysis as a tool to investigate the therapeutic mechanisms and drug development of Chinese Medicinal Herbs. Biomed. 2:10-
6.

Li, Y, Liu, Y, Xiu, F, Wang, J, Cong, H, et al, 2018: Characterization of exosomes derived from To-xoplasma gondii and their functions in modulating immune responses. Int. J. Nanomed. 13:467-77.

Kashyap, D, Sharma, A, Sak, K, Tuli, HS, Buttar, HS, Bishayee, A, 2018: Fisetin: A bioactive phytochemical with potential for cancer prevention and pharmacotherapy. Life Sci. 194: 75-87.

Kim, HJ, Kim, SH, Yun, JM, 2012: Fisetin inhibits hyperglycemia-induced proinflammatory cytokine production by epigenetic mechanisms. Evid. Based Complement. Alternat. Med. 12:639469.

Kotz, S, Balakrishnan, N, Read, CB, 2006: Vidakovic B. Encyclopedia of Statistical Sciences. $2^{\text {nd }}$ ed. Hoboken, N.J.: Wiley-Inter-Science. Leesombun, A., Boonmasawai, S, Shimoda, N, Nishikawa, Y, 2016: Effects of extracts from Thai Piperaceae plants against infection with Toxoplasma gondii. PLoS One 11:e0156116.

Lowery, OH, Rosebrough, NJ, Farr, AL, Randall, RJ, 1951: Protein measurement with the Folin phenol reagent. J. Biol. Chem. 193:265-75. Maher, P, Dargusch, R, Ehren, JL, Okada, S, Sharma, K, et al, 2011: Fisetin lowers methylglyoxal dependent protein glycation and limits the complications of diabetes. PLoS One 6: e21226.

Manjolin, LC, Reis, MB, Maquiaveli, CC, Santos-Filho, OA, Roberto da Silva, EP, 2013: Dietary flavonoids fisetin, luteolin and their derived compounds inhibit Arginase, a central enzyme in Leishmania (Leishmania) amazonensis Infection Food Chem. 141:2253-62.

Manuel, L, Gomes, GS, Noormahomed, EV, 2020: Human toxoplasmosis in Mozambique: Gaps in knowledge and research opportunities. Parasit. Vectors 13, 1:571-80.

Martínez-Castillo, M, Pacheco-Yepez, J, Flores-Huerta, N, Guzmán-Téllez, P, Jarillo-Luna, RA, et al, 2018: Flavonoids as a natural treatment against Entamoeba histolytica. Front. Cell. Infect. Microbiol. 8:209-12.

Mehta, P, Pawar, A, Mahadik, K, Bothiraja, C, 2018: Emerging novel drug delivery strategies for bioactive flavonol fisetin in biomedicine. Biomed. Pharmacother. 106:1282-91.

Merken, HM, Beecher, GR, 2000: Measurement of food flavonoids by high-performance liquid chromatography: A review. J. Agric. Fo- 
od Chem. 48:77-99.

Mesquita, JT, Tempone, AG, Reimão, JQ, 2014: Combination therapy with nitazoxanide and amphotericin B, Glucantime ${ }^{\circledR}$, miltefosine and sitamaquine against Leishmania (Leishmania) infantum intracellular amastigotes. Acta Trop. 130:1121-16.

Mordue, DG, Monroy, F, La Regina, M, Dinarello, CA, Sibley, LD, 2001: Acute toxoplasmosis leads to lethal overproduction of Th1 cytokines. J. Immunol. 167:4574-84.

Naeem, H, Sana, M, Islam, S, Khan, M, Riaz F, et al, 2018: Induction of Th1 type-oriented humoral response through intranasal immunization of mice with SAG1-Toxoplasma gondii polymeric nanospheres. Artif. Cells Nanomed. Biotechnol. 46: 1025-34.

Pal, HC, Pearlman, RL, Afaq, F, 2016: Fisetin and its role in chronic diseases. Adv. Exp. Med. Biol. 928:213-44.

Pardini, L, Bernstein, M, Carral, LA, Kaufer, FJ, Andrea Dellarupe, A, et al, 2019: Congenital human toxoplasmosis caused by non-clonal Toxoplasma gondii genotypes in Argentina. Parasitol. Int. 68, 1:48-52

Pereira, AC, Silva, RJ, Franco, PS, Gomes, A O, Souza G, et al, 2019: Cyclooxygenase (COX)-2 inhibitors reduce Toxoplasma gondii infection and upregulate the pro-inflammatory immune response in Calomys callosus rodents and human monocyte cell line. Front. Microbiol. 10:225-9.

Peters, PJ, Thigpen, MC, Parise, ME, Newman, RD, 2007: Safety and toxicity of sulfadoxine/pyrimethamine: implications for malaria prevention in pregnancy using intermittent preventive treatment. Drug Saf. 30, 6:481-501

Pu, J, Wan, L, Zheng, D, Wei, X, Wu, Z, et al, 2017: Fisetin alleviates hypoxia/reoxygenation injury in rat hepatocytes via modulation of TL R4/NF-кB signaling pathway. Xi. Bao. Yu. Fen. Zi. Mian. Yi. Xue. Za. Zhi. 33:936-41.

Robert-Gangneux, F, Dardé, ML, 2012: Epidemiology of and diagnostic strategies for toxoplasmosis. Clin. Microbiol. Rev. 25:264-96.

Ryoyama, K, Nomura, T, Nakamura, S, 1993: Inhibition of macrophage nitric oxide productionby arachidonate-cascade inhibitors. Canc. Im munol. Immunother. 37:385-91

Saadatnia, G, Golkar, M, 2012: A review on the human toxoplasmosis. Scand. J. Infect. Dis. 44, 11:805-14.

Sahu, BD, Kalvala, AK, Koneru, M, Mahesh
Kumar, J, Kuncha, M, et al, 2014: Ameliorative effect of fisetin on cisplatin-induced nephrotoxicity in rats via modulation of NF- $\kappa \mathrm{B}$ activation and antioxidant defence. PLoS One 9: e105070.

Saleh, AMA, Ali, HA, Ahmed, SAM, Hosny, S M, Morsy, TA, 2014: Screening of Toxoplasma gondii infection among childbearing age females and assessment of nurses' role in prevention and control of toxoplasmosis. J. Egypt. Soc. Parasitol. $44,2: 329-42$

Silva, LA, Fernandes, MD, Machado, AS, Reis-Cunha, JL, Bartholomeu, DC, et al, 2019: Efficacy of sulfadiazine and pyrimetamine for treatment of experimental toxoplasmosis with strains obtained from human cases of congenital disease in Brazil. Exp. Parasitol. 202:7-14

Stephen, S, Pradeep, J, Anitharaj, V, Janarthanam, V, 2017: Seroprevalence of toxoplasmosis involuntary blood donors of Puducherry and surrounding districts of Tamil Nadu. J. Parasit. Dis. 41, 4: 1158-61.

Wang, J, Zhao, XH, 2016: Degradation kinetics of fisetin and quercetin in solutions affected by medium $\mathrm{pH}$, temperature and co-existed proteins. J. Serb. Chem. 81: 243-253.

Wei, HX, Wei, SS, Lindsay, DS, Peng, HJ, 2015: A Systematic review and meta-analysis of the efficacy of anti-Toxoplasma gondii medicines in humans. PLoS One 10:e0138204.

Weitberg, AB, Alper, JC, Diamond, I, Fligiel, Z, 1979: Acute granulomatous hepatitis in the course of acquired toxoplasmosis. N. Engl. J. Med. 300: 093-1096.

Woods, S, Schroeder, J, McGachy, HA, Plevin, R, Roberts, CW, et al, 2013: MAP kinase phosphatase-2 plays a key role in the control of infection with Toxoplasma gondii by modulating iNOS and arginase-1 activities in mice. PLoS Path. 9:e1003535.

Xia, Y, Zweier, JL, 1997: Measurement of myeloperoxidase in leukocyte-containing tissues. Anal. Biochem. 245:93-6.

Xu, SP, LI, YS, 2018: Fisetin inhibits pristineinduced systemic lupus erythematosus in a murine model through CXCLs regulation. Int. J. Mol. Med. 42:3220-30.

Zhang, R, Zhang, H, Liu, X, Fu, Q, Xu, X, et al, 2012: The immunoprotective role of interleukin-10 in abnormal pregnancy outcomes in duced by Toxoplasma gondii infection. Gynecol. Obst. Invest. 73: 223-9 


\section{Explanation of figures}

Fig. 1: Kaplan Meier curve showed survival rate of mice in different groups. Cum. survival: cumulative survival, OS time: overall survival time. II: G2, III: G3, IV: G4, V: G5, VI: G6, VII: G7.

Fig. 2: Liver impression smears stained with Giemsa from $T$. gondii infected untreated G2 showed A) Condensed tachyzoites (black arrow) (x 1000). B) Free tachyzoites (black arrows) and pseudocysts (white arrows) (x 1000)
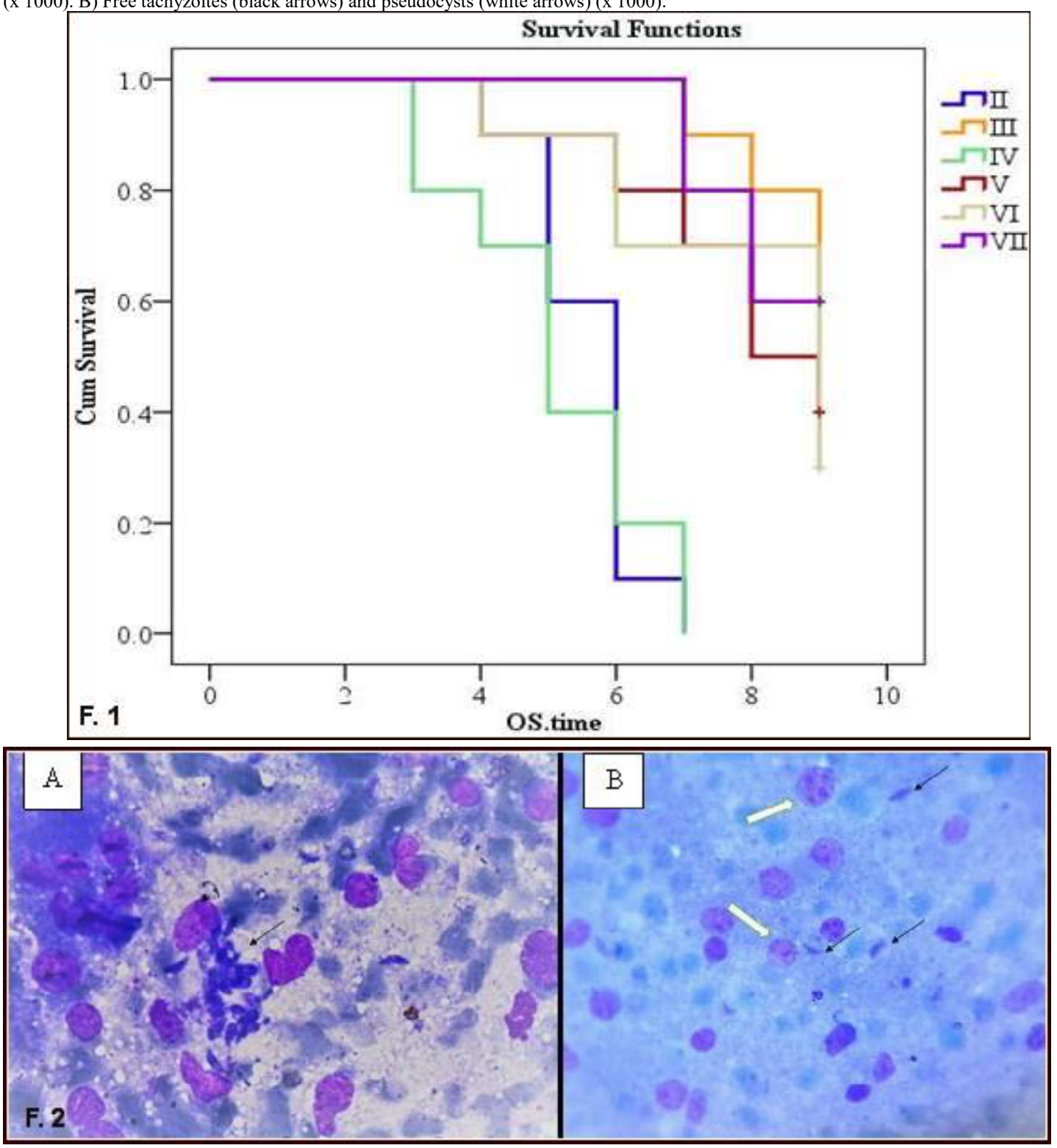